\title{
Models of tax relations: improving the tax culture and discipline of taxpayers in the interests of sustainable development
}

\author{
Irina Korostelkina ${ }^{1 *}$, Elena Dedkova ${ }^{1}$, Natalia Varaksa $^{1}$, and Mikhail Korostelkin ${ }^{1}$ \\ ${ }^{1}$ Orel State University, Department of Economics, Finance and accounting, 40 Naugorskoe highway, \\ 302020, Orel, Russia
}

\begin{abstract}
Modern globalization and global integration increase the importance of social processes in the economy, while the human factor plays a significant role in all spheres. Sustainable development in general and certain areas of life, including tax relations, are no exception. Taxes are a socially necessary phenomenon, the basis of the financial mechanism for sustainable development, and are the most important basic regulator of social progress. Through taxes, a social balance is achieved between public, corporate, and personal economic interests. The article examines the existing models of tax relations (characterizing the interaction of the state and taxpayers from the point of view of the principles of force, law and partnership), the possibility of their successful implementation and improvement. The current model of tax relations in the state entails appropriate tax behavior on the part of taxpayers and tax authorities. Tax behavior models are based on a certain level of tax culture and morality, which is formed under the influence of a number of objective and subjective factors. Tax culture, tax behavior and discipline, the process of interaction between the state and taxpayers (the level of development of tax relations) and determine the degree of protection of national interests and sustainable development.
\end{abstract}

\section{Introduction}

Sustainable development is a new philosophy, according to which economic agents act and make any management decision taking into account socio-economic and natural production factors. The concept of sustainable development includes people (the sociosphere), nature (the environment), and the economy. Human behavior in the tax sphere (a socio-economic subjective factor) affects tax discipline, tax culture, and the relationship between the state and economic agents. On the other hand, this relationship is significantly affected by the model of tax relations chosen by the state. The practice of tax relations shows that currently there is a specific stereotype of the behavior of economic agents [1] and a model of tax culture has been formed, which on the one hand is manifested in the desire to avoid paying taxes, and on the other - in the lack of motivation to perform official duties in good faith.

\footnotetext{
*Corresponding author: cakyra_04@mail.ru
} 
In this regard, we consider it necessary to investigate not only the models of tax behavior and tax relations, the formation and development of tax culture in society, but also to reveal the mechanisms for effective use of the partner model of relations in the tax sphere in the interests of sustainable development.

When starting to analyze the problems of low tax culture and discipline, as well as methods for solving them, it is advisable to consider the main theoretical aspects of the research topic, namely the concepts, the theoretical scientific base, and the historical aspect.

The tax system fits into the concept of sustainable development as a superstructure (tool) that characterizes the level of socio-economic and cultural development of the state. The tax culture, discipline and behavior of taxpayers and tax authorities also depend on the efficiency of functioning and interaction of its elements (the tax system, subjects of tax relations and tax legislation).

Questions of morality, tax culture and behavior of economic agents in the tax sphere are learnt by many domestic and foreign authors. In particular, M. Leroy [2], J. Schumpeter [3] explores fiscal sociology and its cognitive approach. J. Schumpeter, in the framework of fiscal sociology, first investigated the phenomenon of tax culture, by which he understood «the expression of human spirituality and creativity». «Each tax ideal has its own historical, economic, and sociological boundaries». According to Schumpeter tax culture is based both on the traditions of the respective society and on the interaction of values and society [4]. And if in Germany, Switzerland and other Western countries tax culture is considered as a concept of economic sociology, which is based on the society, the attitude of the individual to the tax system (A. Pausch, R. Berger), then in the United States tax culture is considered as a phenomenon of political science. It was politics (Laried Combesta, 1997) that played a crucial role in developing the culture of tax administration and protecting the rights of taxpayers [5].

Tax culture is a multidisciplinary concept, which, on the one hand, is revealed through the activity approach, and on the other - through the process approach. In the first case, selfexpression and self-knowledge of the tax system are manifested through the tax culture. Tax culture is a set of stable forms of tax activity of an economic agent, without which it cannot be reproduced, and therefore exist $[1,6]$. According to the theory of social exchange by $\mathrm{J}$. Homans, tax culture is «a stable product of the exchange of activities of tax and other authorities involved in the tax process, on the one hand, and taxpayers, on the other» $[7,8]$.

In the second case, the administrative influence of the state on economic agents is manifested through the tax culture, since the tax culture forms a certain behavior in the taxpayer. The tax culture participates in the process of tax relations (defining the relationships and interaction of participants), thereby improving the budget sphere and supporting sustainable development. Tax culture determines the level of knowledge of economic entities in the tax sphere and the degree of confidence of citizens in the state policy.

Tax discipline is also closely related to tax culture. According to M.T. Aguzarova [9], F.E. Velieva [10] tax discipline is a regular formation, development and control of the ethical, moral and financial abilities and capabilities of the taxpayer to fulfill tax obligations to budgets, taking into account the synchronicity of interaction of tax authorities in receiving and processing taxes and tax obligations. Thus, tax discipline determines the taxpayer's awareness of the tax obligation to the state, compliance with the requirements of article 57 of the Constitution of the Russian Federation «Everyone is obliged to pay legally established taxes and fees».

Both tax culture and tax discipline are links in the same chain of conscientious behavior of taxpayers and tax authorities. The model of legitimate tax behavior is based on moral and ethical standards, values, and principles of effective taxation. This model, on the one hand, characterizes a person's awareness of the importance of paying taxes (no taxes - the budget does not receive financial resources - the state cannot fulfill its obligations), and on the other 
hand, an understanding among tax officials of the importance of quality performance of official duties (following the law).

Tax evasion creates a moral failure of the taxpayer, a model of unstable (aggressive) behavior.

The activities of tax authorities should be based on moral and ethical principles [11]. At the moment these principles are enshrined in the Code of conduct for public officials (Code of ethics of government services) (USA, 1958), Value the code of ethics for public service (Canada), the code of Ethics for public service (UK, 1997), the Code of ethics and official conduct of civil servants of the Federal tax service (Russia, 2011).

The level of low tax culture in Russia is associated with the historical development of the state. Taxes have always been associated with looting, disasters, wars, and fires. Russia is characterized by a revolutionary way of development, as opposed to the West, where the tax system has evolved. All important reforms (those of Peter I, Ekaterina II, and P.A. Stolypin) that brought States to a higher level of development were accompanied by both social transformation of society and the establishment of a new (increased) tax burden.

The success of tax collection depends on the mentality of the population: if in Russia at all times there was an extremely hostile attitude to taxes, in the West, paying tax is a pride for a person, tax culture is instilled from childhood. Children respect their parents for paying taxes and contributing to the development of their country [12]. Most Western tax theories promoted tax payment as a benefit, a pleasure, a necessity for the state, and formed a positive attitude to the process of paying taxes, thereby developing a tax culture. In particular, J.S. de Sismondi considered the tax as a pleasure «with the help of taxes, each payer buys nothing but pleasure. He derives pleasure from public order, justice, security of the person and property» [13].

In contrast to Western theories, domestic economists linked the payment of taxes directly to the negative impact on the position of the economic agent. N.I. Turgenev in his work «Experience of the theory of taxes» characterized that every type of tax is an evil, because it deprives the payer of part of his property. Since taxes are unavoidable due to their compulsory nature, it is necessary to choose the easiest of them [14].

In addition to moral and ethical norms, the process of forming a tax culture and the behavior of taxpayers is influenced by a psychological factor. This influence was first analyzed by the founder of the classical tax theory, A. Smith, in the work «Research on the nature and causes of the wealth of peoples» [15]. He formulated not only the principles of taxation, which in modern science formed the basis for the formation of tax systems of States, but also studied and analyzed the psychological moment of a person's attitude to taxes. Tax psychology was widely developed in the works of O. Fait «Fundamentals of tax morality», A. Levis «psychology of taxation», as well as representatives of the Cologne school of economic and financial psychology [11].

Therefore, historically established trends have a negative impact on the attitude to taxes, as well as on the level of tax culture and behavior of taxpayers. In modern Russian society, the paradigm «taxes are the basis for the welfare of the state and society» is perceived negatively by citizens.

\section{Research methods}

The methodological basis of the study was based on methods of induction and deduction, analysis, systematization, comparison, graphical representation, and selective observation. The research positions are reasoned using formal, comparative, and functional methods [3].

In particular, the comparative method means analyzing objects of different States, that is, comparing the new state of an object with the old one, or comparing the state of one object 
with another. We used this method to analyze and evaluate domestic and foreign experience in forming tax culture and tax behavior.

The grouping method provides for the structuring of economic phenomena on any basis. This method was used in the study of the conceptual apparatus, the formation of factors that affect the tax culture and tax discipline, and the development of measures to improve the tax culture and discipline of taxpayers in the interests of sustainable development.

The graphical representation method is a visual generalization of information using drawings, graphs, and histograms. This method was used in determining factors that influence the formation of tax culture and behavior of taxpayers, characteristics of tax behavior models of economic agents, identifying factors that determine the choice of model, building the framework structure of the tax behavior model and the model of interaction of elements of tax culture, behavior and interaction of the state and taxpayers in the interests of sustainable development.

\section{Discussion and results}

Sustainable development of the state, national security and economic growth is ensured by an effective system of relations between society and the state authorities. In the tax sphere, this is manifested in the interaction of management bodies (tax and financial authorities), economic agents and intermediaries (tax consultants).This issue was identified as fundamental in creating an effective tax administration system both in 2006 (the «Seoul Declaration») and in 2007 at the Conference of the European Confederation of tax consultants. In world practice, there are three models of relations: from the positions of power, law, and interests, the comparative characteristics of which are presented in table 1.

Table 1.Characteristics of tax relationship models.

\begin{tabular}{|c|c|c|c|}
\hline Model & Description & Advantages & Disadvantages \\
\hline $\begin{array}{l}\text { The power } \\
\text { model of tax } \\
\text { relations (from } \\
\text { the position of } \\
\text { power) }\end{array}$ & $\begin{array}{l}\text { It involves the use } \\
\text { of mechanisms to } \\
\text { compel taxpayers to } \\
\text { perform their } \\
\text { taxduties }\end{array}$ & $\begin{array}{l}\text { completely solves the } \\
\text { problem of collecting } \\
\text { taxes and forming the } \\
\text { revenue part of the } \\
\text { budget }\end{array}$ & $\begin{array}{l}\text { - business activity decreases; } \\
\text { - civilized relations between } \\
\text { taxprocess participants are } \\
\text { violated; } \\
\text { - increased resources for tax } \\
\text { administration; } \\
\text { - provokes the use of illegal } \\
\text { ways of interaction between the } \\
\text { state and taxpayers }\end{array}$ \\
\hline $\begin{array}{l}\text { The legal } \\
\text { model of tax } \\
\text { relations (from } \\
\text { the point of } \\
\text { view of law) }\end{array}$ & $\begin{array}{l}\text { It involves building } \\
\text { relationships based } \\
\text { on legal norms. In } \\
\text { case of disputes, the } \\
\text { decision is made by } \\
\text { the court }\end{array}$ & $\begin{array}{l}\text { uses the principles of } \\
\text { fairness and } \\
\text { predictability }\end{array}$ & $\begin{array}{l}\text {-provokes legal confrontation; } \\
\text { - encourages dishonesty of } \\
\text { taxpayers and aggressive tax } \\
\text { planning; } \\
\text { - reduced incentives to use legal } \\
\text { dispute resolution methods }\end{array}$ \\
\hline $\begin{array}{l}\text { The } \\
\text { partnership } \\
\text { model of tax } \\
\text { relations } \\
\text { (position of } \\
\text { interest) }\end{array}$ & $\begin{array}{l}\text { Assumes the state's } \\
\text { desire to achieve a } \\
\text { balance of interests } \\
\text { of participants in } \\
\text { taxrelations }\end{array}$ & \multicolumn{2}{|c|}{$\begin{array}{l}\text { Advantages:implements the principle of cooperation, that } \\
\text { is, honest communication of information to the } \\
\text { participants of taxrelations, as well as consultations and } \\
\text { out-of-court conflict resolution }\end{array}$} \\
\hline
\end{tabular}

In the West, it is the partner model of tax relations that has become the most widespread. For Russia, this model is a new one, replacing the model of power-subordination, that is, an intermediate position between the power and legal models [16]. 
In the tax sphere, the concept of sustainable development should be implemented through the process of forming an educated and cultured taxpayer. According to N.B. Musetova [17] an «educated» taxpayer is a person who has legal knowledge. The concept of a «cultural» taxpayer appears when a person is ready to correctly and rationally fulfill their tax obligations, perceiving it as their civil duty. The process of forming a «cultural» taxpayer is influenced by the sphere of professional activity and the level of children's tax literacy: the formation of a tax culture must be laid down in the person initially. Therefore, the state should pursue a policy of advanced development (following the example of Western countries) aimed at correctly understanding the essence of taxes and the need to pay them, and, as a result, increasing the level of tax culture.

The level of tax culture and discipline of economic agents directly affects tax behavior. Tax behavior is an element of economic behavior related to tax relations. On the part of taxpayers, tax behavior is determined by the correctness of the calculation, timeliness of tax payment, fair interaction with contractors, and law-abiding attitude to the formation of the tax field and tax reporting. On the part of tax authorities, tax behavior is determined by the level of cultural interaction with taxpayers, timely information and performance of official duties, lack of vested interests and corrupt behavior.

The process of forming a tax culture in society and the behavior of taxpayers is influenced by a combination of subjective and objective factors (Fig. 1).

It is advisable to use the best Western practices for developing a partner model of tax behavior in order to increase tax culture, discipline, and trust of taxpayers and foster good faith.

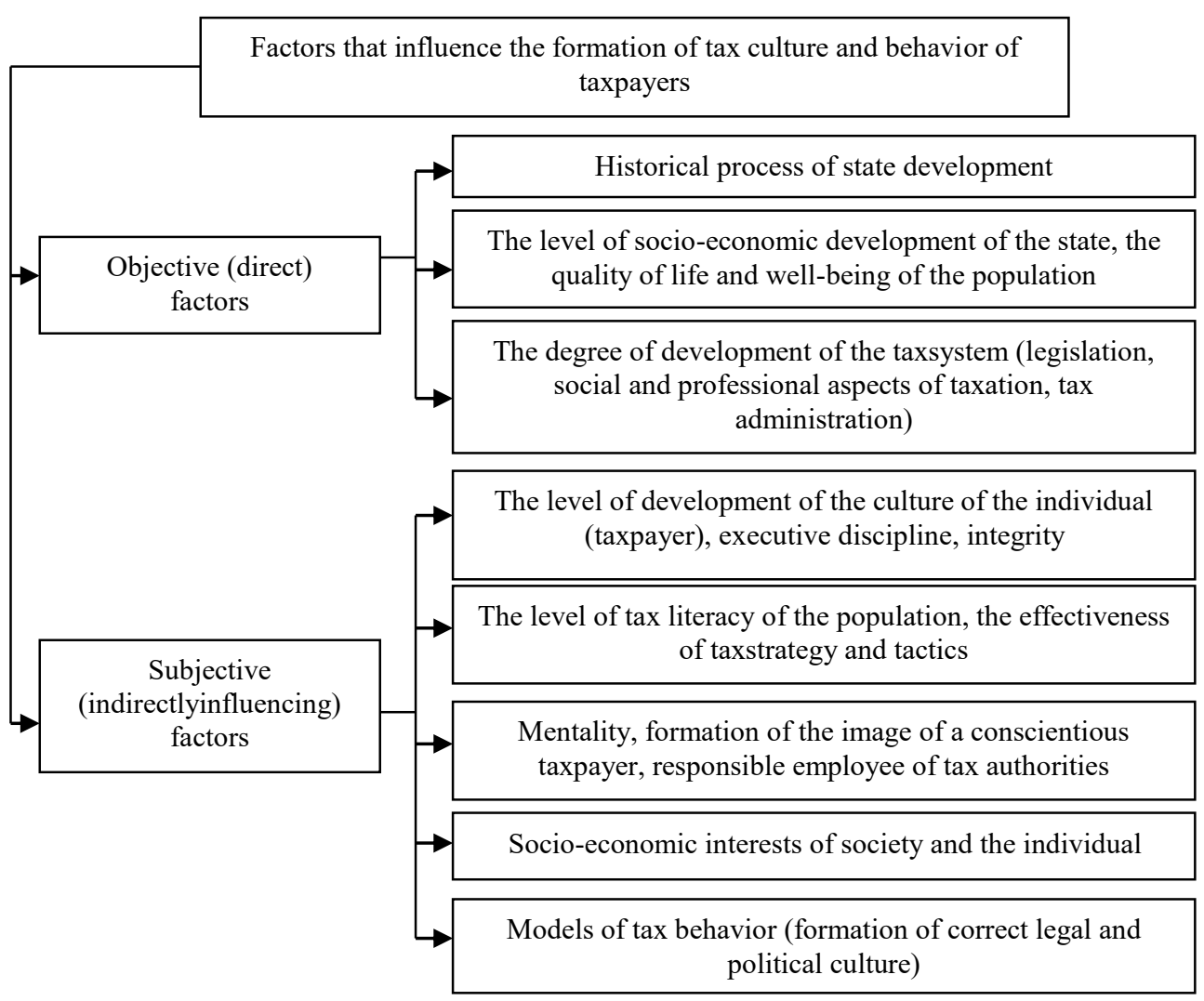

Fig. 1. Factors that influence the formation of tax culture and behavior of taxpayers 
To implement the partner model of tax relations in practice, it is necessary:

- to fix at the legislative level the principles of cooperation and protection of taxpayers trust as fundamental in the relationship between the state and economic agents;

- introduce the possibility and conditions for concluding preliminary agreements [16] and pre-trial settlement of tax disputes into the practice of tax relations;

- regulate the Institute of tax consulting.

It is necessary to instill tax knowledge from childhood (for example, the United States, Japan, and Canada) by holding local and national children's competitions, broadcasting and disseminating information in the media, introducing the basics of taxation in schools as a mandatory lesson, and conducting other educational work.

The level of tax culture also depends on the mentality. Scandinavian countries (Finland, Sweden) have the highest level of tax culture. This is manifested in the incompatibility of two components from a practical point of view: the development of an innovative economy and a high level of tax culture. In Finland, citizens trust the state to pay legally established taxes, while the state, despite the high tax burden (about 44.13\% in 2016) (according to the OECD) [18] (Fig. 2), does not suppress incentives for business development, provides the population with high social guarantees and conditions for a comfortable existence [17].
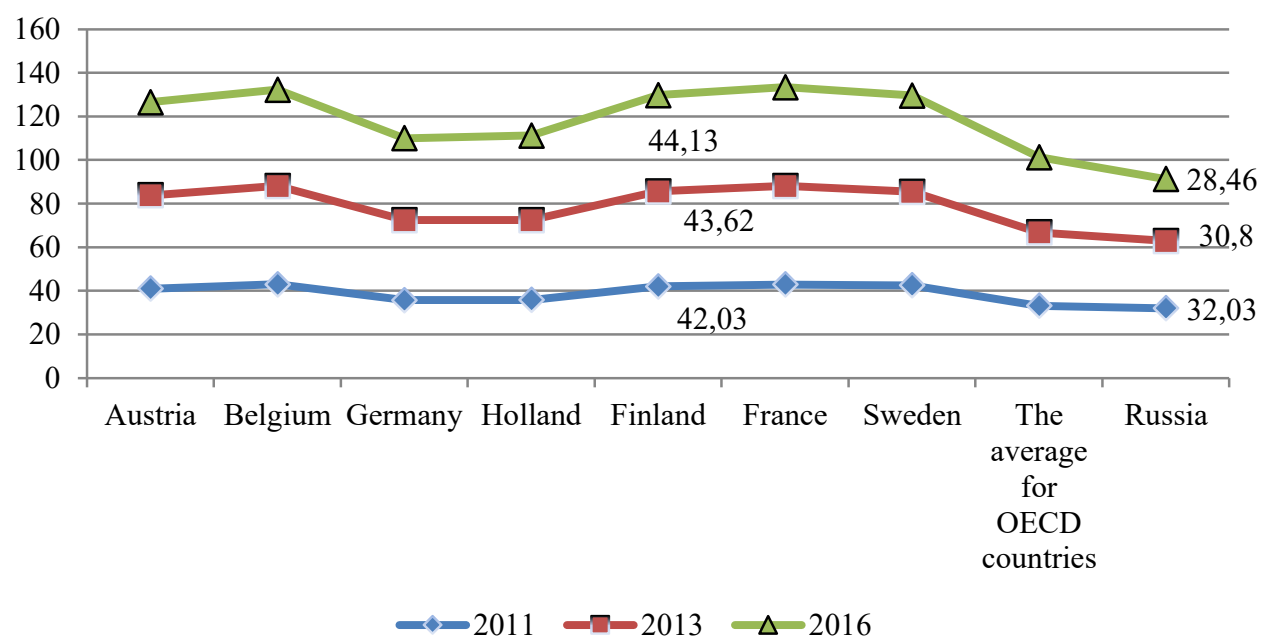

Fig. 2. Tax burden on the economy in OECD countries, \% of GDP (compiled by [18]).

Tax behavior directly depends on the level of tax culture and tax literacy. In practice, there are several forms (models) of tax behavior that are determined by the specifics of taxpayers. A.V. Galukhin [19], T.V. Merkulova [20] identify conscientious (law-abiding), uninformed, negligent taxpayers and taxpayers who knowingly evade paying taxes. This classification of taxpayers generates the following models of tax behavior (Fig. 3).

The first model provides for strict compliance with tax legislation, when an organization pays taxes in full without seeking to optimize its payments in any way and reduce the tax burden. This model of tax behavior is the least common in modern society.

Tax evasion, as one of the models of tax behavior, generates a large number of tax risks associated with both material losses and loss of business reputation.

A model that involves risky tax behavior is typical for taxpayers who do not have the desire to become «educated» (study laws, judicial tax practice, use the services of tax consultants), so they resort to using questionable (illegal) methods of optimization. As a result of risky behavior of taxpayers, if it is formally correct at the time of implementation of 
optimization schemes, the economic effect of them becomes zero or even negative, taking into account the emerging risks (high costs for legal disputes, recalculation of the amount of tax liabilities, etc.).

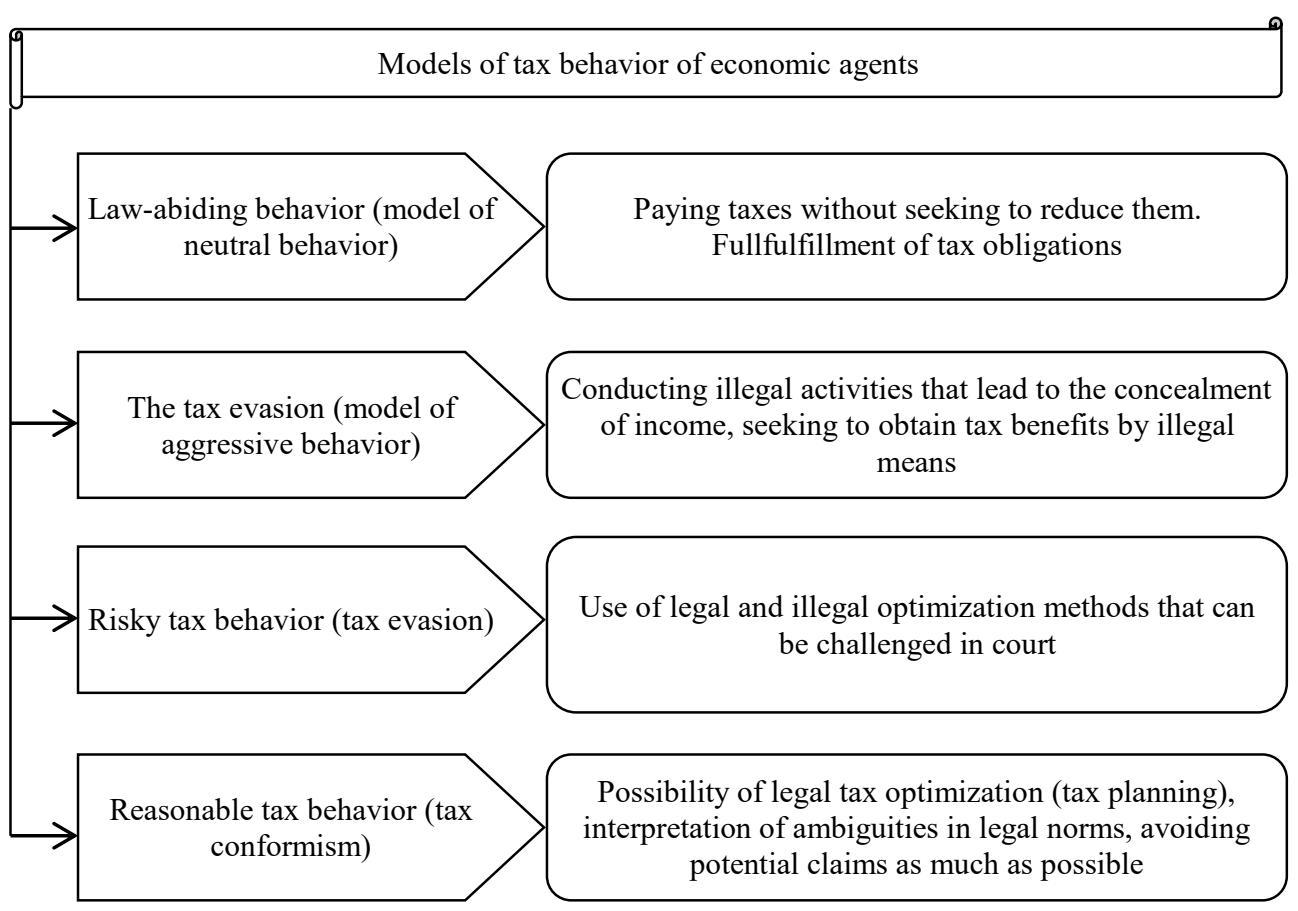

Fig. 3. Models of tax behavior of economic agents (compiled by [21], [22]).

The model of reasonable tax behavior provides for the possibility of tax optimization due to a number of reasons:

1) civil rights to choose the legal form and form of ownership;

2) the right to independently determine the tax regime;

3) the possibility of choosing different methods of accounting for business transactions within the tax legislation.

That is, in fact, the model of reasonable tax behavior provides for the use of tax legislation to reduce the tax burden.

Of course, for sustainable development, taxpayers must adhere to the model of tax conformism, since offenses involving non-payment or incomplete payment of taxes represent an uncivilized form of interaction between participants in the tax process and mainly relate to the power model of tax relations. At the same time, the opinion of an economic agent is subjective and not always economically justified [19].

A number of factors, both tax and non-tax, influence the taxpayer's choice of a particular model of tax behavior (Fig. 4).

The «ideal» model of tax behavior of economic agents is structured by us as a three-level model that takes into account the individual characteristics of economic agents (Fig. 5).

At the first level, a universal model of tax behavior is formed, genetically inherited by society, which arose as a result of evolutionary values and principles of morality and morality. At the second level, there is a model of tax behavior used by a group of economic agents (a specific industry, region, etc.). This model creates an «educated» taxpayer. 


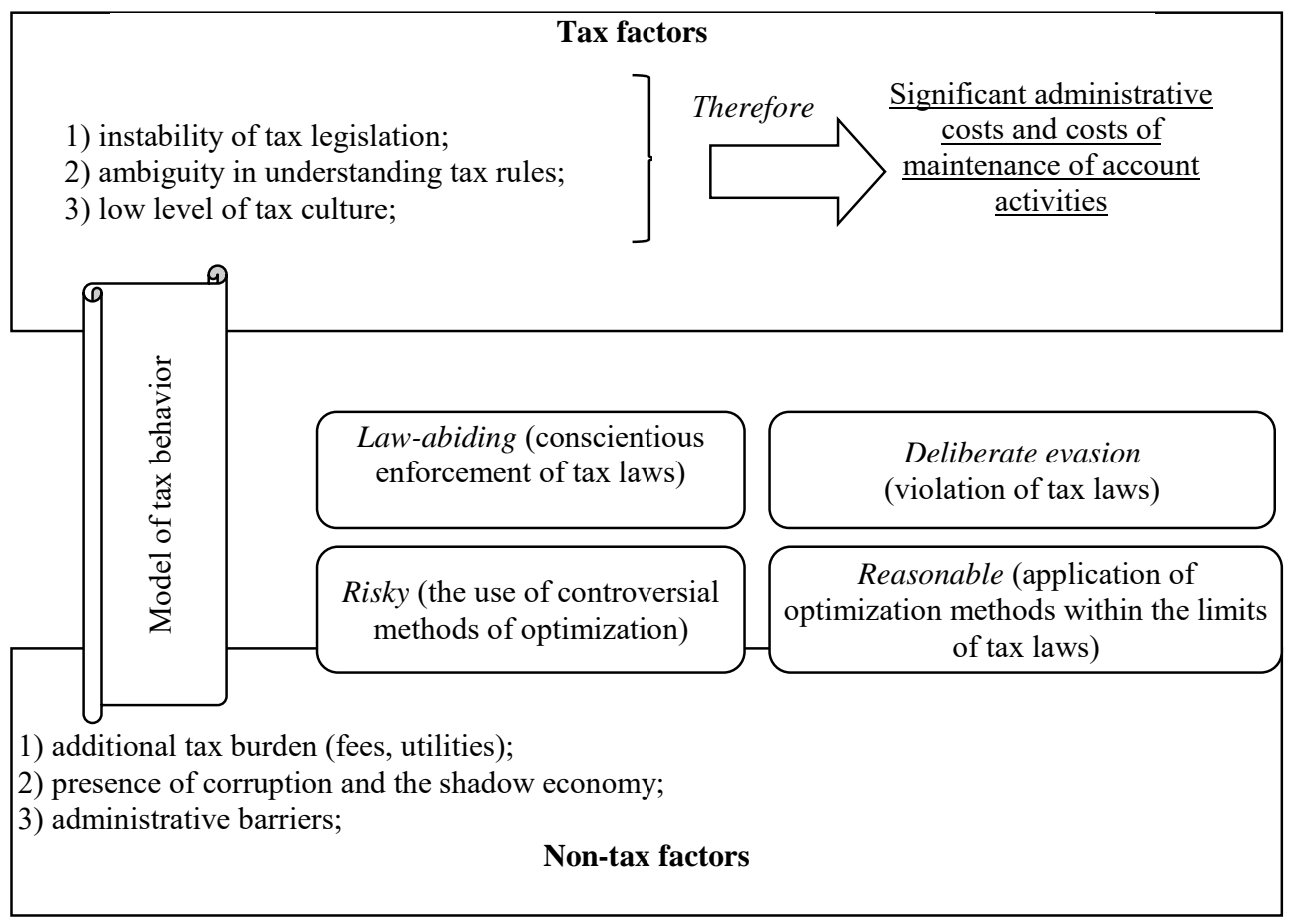

Fig. 4. Factors that determine the choice of tax behavior model for economic agents.

At the third (highest) level, there is a model of tax behavior that is characteristic of the individual (a particular individual). This model is a symbiosis of genetically inherited moral and ethical norms and characteristics of the «educated» taxpayer. At this level, the phenomenon of the «cultural» taxpayer is formed [8].

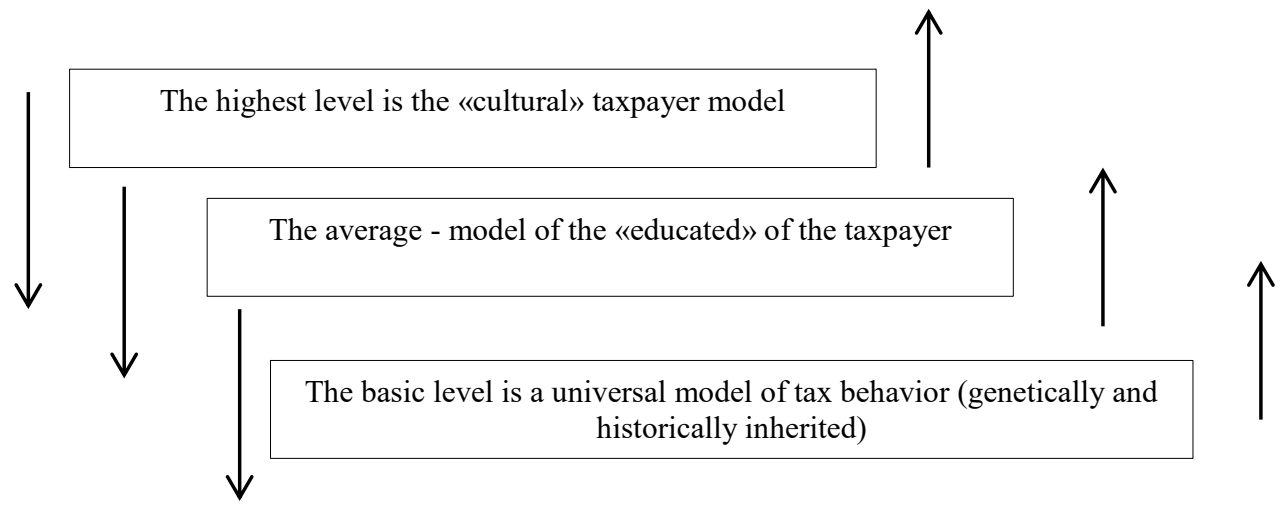

Fig. 5. Formation of an «ideal» model of tax behavior of economic agents.

The second and third (highest) levels of the model include the values of society in the motives of taxpayers, taxes are perceived as a public good, and trust in the state is increased. This model will not only determine the tax behavior of the taxpayer, but also identify the threats and risks of its activities for the purpose of sustainable development. 
Building effective relations between the state and economic agents is the most difficult state task [23], the solution of which is possible with a sufficient level of tax culture and reasonable tax behavior (tax conformismmodel).

Taking into account the current model of tax relations in society, issues of tax culture and discipline of taxpayers should be considered from two positions, which will simultaneously serve as directions for increasing their level (Fig. 6).

Directions for improving the level of tax culture of the society and the discipline of taxpayers
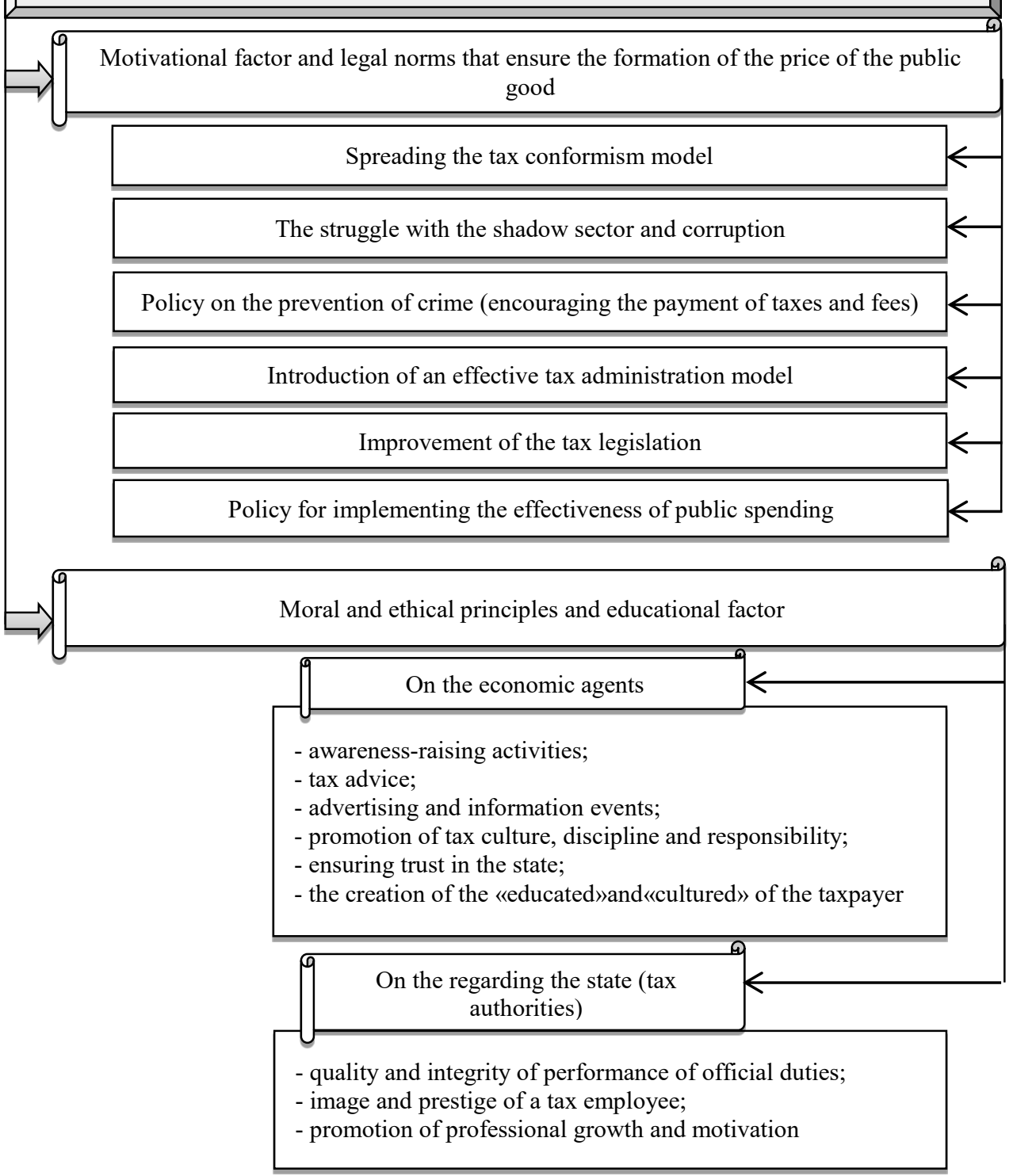

Fig. 6. Ways to improve the level of tax culture of the society and discipline of taxpayers.

In the first case, tax culture is considered as a process directly related to the formation of the price of a public good. Thus, we can talk about the tax culture of the state and the tax culture of an individual taxpayer [24]. The level of tax culture of the state, according to D.O. 
Kasimov, determined by the degree of compliance (non-compliance) provided public goods (volume and quality) the level of tax burden in the economy, the size of the gap assessed and actually paid taxes, the volume of «shadow economy» in GDP, indicators of tax evasion [24].

In 2015, the share of Russia's shadow economy according to the IMF was $33.7 \%$ of GDP. In developed countries (the United States, the Netherlands, Japan, Switzerland, and Singapore), the indicator ranges from $7 \%$ to $15 \%$ of GDP [25]. In 2017 , it reached $38.3 \%$ of world GDP (Fig.7), so this phenomenon is of increasing interest to experts [26]. The scale of the shadow economy in Europe in 2017 ranged from 6.5-22.4\% of GDP, in the US - 5.9\%, in Russia-about $50 \%$ of GDP [25]. Thus, statistics once again confirm the low tax culture of Russian society and the need to form a partner model of tax relations.

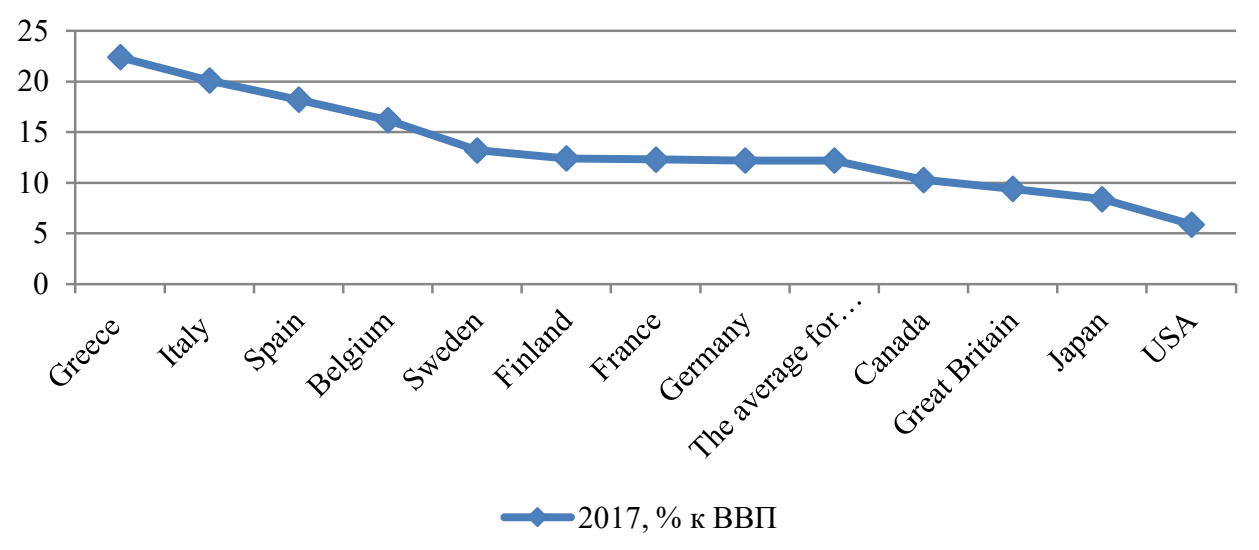

Fig. 7. The level of the shadow economy in relation to GDP in 2017, in \% [27].

In the second case, the tax culture is directly related to the educational process that involves raising tax literacy and conducting awareness-raising work, and moral and ethical principles.

The mechanism for creating a tax culture for sustainable development consists of the process of developing a tax culture:

- the individual (taxpayer) based on value orientations, needs and expectations;

- employees of tax authorities based on moral and ethical standards and current tax policy;

- other participants in tax relations (financial and legal institutions). Among the latter, many scientists in Russia and abroad include tax consultants.

Thus, the process of forming a tax culture and ensuring proper discipline (appropriate behavior model) is influenced on the one hand by the tax authorities, and on the other by the Institute of tax consulting. Tax authorities, because of their power relations in the interests of sustainable development, exert a controlling influence on the sociosphere (tax culture, behavior, and discipline), and tax consultants help economic agents acquire the status of an «educated» taxpayer. In addition to providing consulting services, tax consultants conduct various trainings, explain legal norms, and help in choosing the most effective model of tax behavior. And it is the close interaction of tax authorities and consultants that makes it possible for an «educated» taxpayer to become «cultured». However, in Russia, the Institute of tax consulting is not regulated, unlike in Western countries, where tax consulting is considered an independent type of professional activity. R. Busse and R. Dernberg [28, 29] abroad, there are two models of regulatory regulation of tax consultants activities:

- system of «state regulation», including a special law on tax advice (Austria, Hungary, Germany, Italy, Poland);

- system of "self-regulation», in which there is no legal basis, but there are rules established by the participants themselves (professional public organizations) (Belgium, 
great Britain, Holland, Ireland, Spain). Such standards include, for example, the ethical principles of tax consultants in Europe, adopted by the General Assembly of the European Confederation of tax consultants in 1991.

In Russia, in the absence of a special law on tax consulting, the tax authorities-taxpayertax consultant relationship is structured as follows: tax authorities interact with taxpayers strictly within the law and can cooperate with professional associations of tax consultants on the principle of cooperation (partnership), tax consultants interact with taxpayers exclusively on a contractual basis, at the same time, they must be members of professional associations and can represent the interests of taxpayers in the tax authorities (on the basis of a power of attorney) [11].

This scheme provides for more effective tax control and the ability to respond to violations in a timely manner, while the taxpayer ensures legal certainty of relations with the state in the tax sphere.

The model of interaction of elements of tax culture, behavior and interaction of the state and taxpayers in the interests of sustainable development is presented in fig.8.

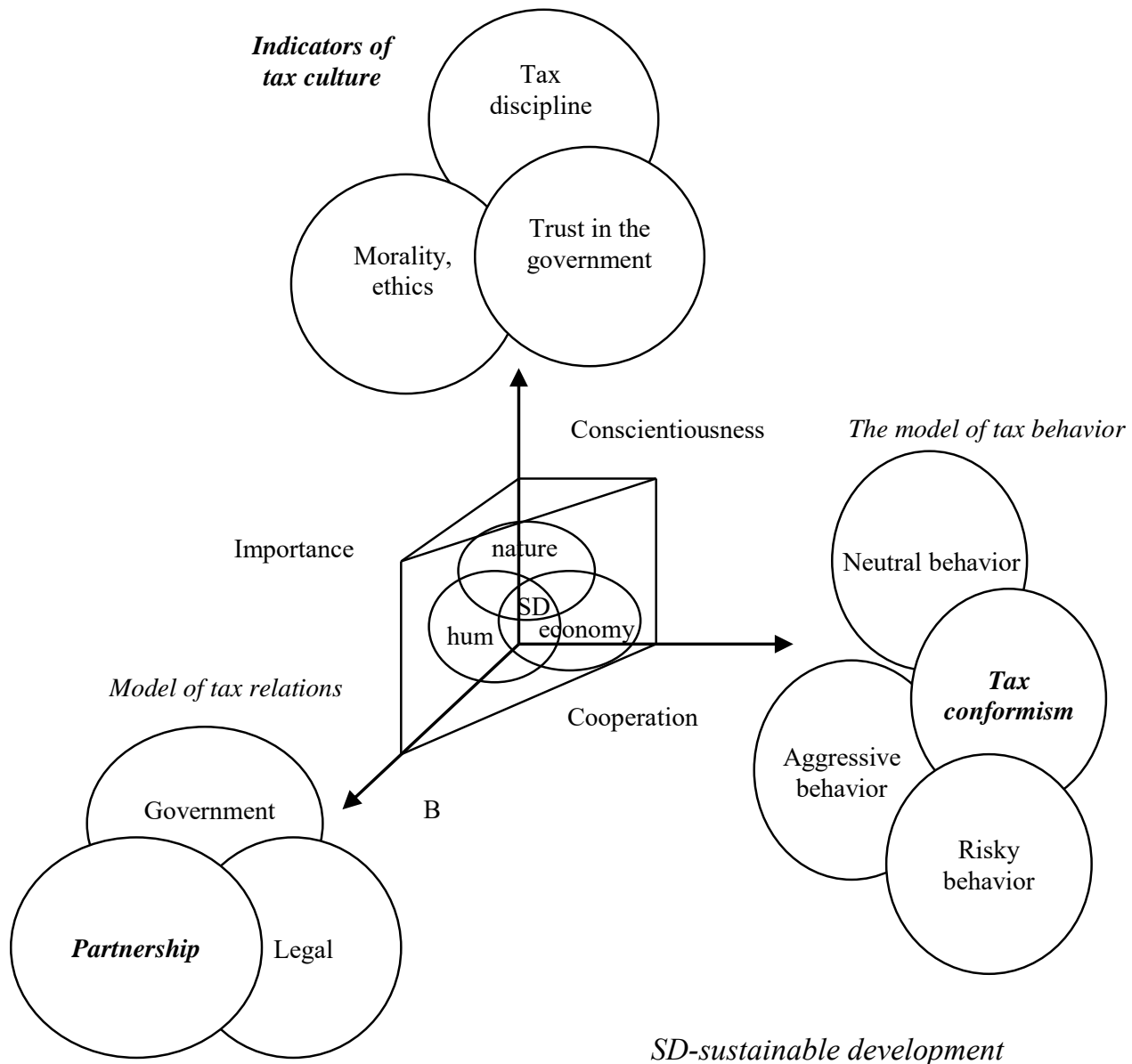

Fig. 8. Model of interaction of elements of tax culture, behavior and interaction of the state and taxpayers in the interests of sustainable development (built by the authors). 
The world practice of building tax relations is based on the principle of cooperation. The high tax culture of European society, the United States, and Japan proves the effectiveness of the partner model of tax relations, since all participants in the tax process receive benefits by mutually maintaining a balance of interests.

This ensures the sustainable development of society and the economy. This is the state that the Russian Federation should strive for.

\section{Conclusion}

In General, increasing the level of tax culture, reducing opportunism in the tax behavior of taxpayers, and developing a partner model of tax relations will help increase tax collection, increase the state's resource capabilities in implementing social guarantees, and ensure sustainable development.

The formation of a tax culture and the choice of a tax behavior model is a two-way process, the result of which depends on both taxpayers and the state. Partnership in tax relations, the desire to balance interests, ultimately, for the state will lead to constructive interaction of individuals, economic agents and government agencies, a better level of development of the tax system.

\section{References}

1. R. D. Murodov Tax culture in the system of tax relations, Fundamental research, 424428, 6 (2016)

2. M. Leroy, Sociology of tax: per with FR. - M.: Business and Service, 96p. (2006)

3. J. A. Schumpeter, Theory of economic development.- M.: Direct media publishing, 401p. (2008)

I. A. Korostelkina, N. V. OvchinnikovaSocial aspects of the tax system functioning, Management accounting, 43-50, 7 (2019)

4. G. G. Sillaste, Economic sociology.-M.: Alpha-M: SIC INFRA-M, 480 p. (2013)

5. V. R. Burnasheva, Value of tax culture in effective tax activities of the state, VestnikKazNU (2013) [Electronic resource]. - Mode of access: https://articlekz.com/article/8663

6. G. C. Homans, Social behavior: Its elementary forms. - N.Y.; Burlingame: Harcourt, Brace \& World Inc. (1961)

7. D. O. Kasimov, Interrelation of taxation and culture, Kazan science, 97-100, 1 (2012)

8. M. T. Aguzarova, M. B. Gusalova, O.O. Burnatseva, Influence of tax culture and tax discipline on economic development, Scientific news, 12-17, 8 (2017)

9. F. E. Veliyeva, Actual problems of tax culture of the Republic of Dagestan, New science: current state and ways of development, 85-88, 12-1 (2016)

10. E. A. Khalikova, D. R. Giniyatullina, Formation of tax culture in Russia, Modern management technologies, 11 (2014) [Electronic resource]. - Mode of access: https://sovman.ru/article/4711/

11. R. Sh. Abakarova, Tax culture of Russia, Theory and practice of social development, 6 (2014) [Electronic resource]. http://cyberleninka.ru/article/n/nalogovaya-kultura-rossii

12. J. S. de Sismondi, New beginnings of political economy or of wealth in its relation to population; TRANS. edited by A.F. Kohn. - M.: State social service. Econ. ed.(1937)

13. N. I. Turgenev, Experience of tax theory.- M.: Sotsekgiz, 176 p. (1937)

A. Smith, Research on the nature and causes of the wealth of peoples. - M.; Leningrad: State social center. Econ. ed., 436 p. (1931) 
14. V. Tsvetkov, Partnership in the tax sphere: myth or reality?, Tax expert, 6 (2008) [Electronic resource]. - Mode of access: http://nalogoved.ru/art/1622.html

15. N. B. Musetova, Tax culture and accountability of the state as necessary elements of an effective tax system in the Republic of Kazakhstan, Young scientist, 291-294, 16 (2017)

16. Revenue Statistics: 1965-2016. OECD iLibrary [Electronic resource]. - Mode of access: https://www.oecd-ilibrary.org/taxation/revenue-statistics-1965-2016/taxrevenue-trends-1965-2016 rev stats-2017-4-en

A. V. Galukhin, On the issue of tax behavior and increasing the tax culture of taxpayers, Social space, 1-7, 1, (2019)

17. T. V. Merkulova, Tax behavior: institutional aspects of analysis, Scientific works of DonNTU, 159-165, 89-3 (2005)

A. E. Miller, T. N. Bogoslavets, Tax behavior of tax inspectors, Bulletin of Omsk University. Economy Series, 180-186, 2 (2016)

II. O. Grebenchuk, Tax Evasion as a deviant form of tax behavior of entrepreneurs, Russian entrepreneurship, 50-53, 10 (2008)

18. A. Bolotova, L. A. Ivanchenko, Raising the level of tax culture as a basis for preventing tax crime, Actual problems of aviation and cosmonautics, 312-314, 9, (2013)

19. D. O. Kasimov, Need to improve tax culture in Russia, Bulletin of the Saratov state social and economic University,123-126, 1 (2012)

20. M. V. Kovaleva, V. A. Lapshov, E. V. Chentsova, Shadow economy as a systemic threat to economic security, Theory and practice of modern science, 390-394, 6 (2017)

21. IMF published an estimate of the size of the shadow economy around the world [Electronic resource] - access Mode: https://www.newsru.com/finance/07feb2018/imfassess.html

22. M. V. Rybasova, Analysis of the scale of development of the shadow economy in Russia,Collection of articles based on the materials of the III international scientific and practical conference «Scientific forum: Economics and management».- M., Publishing house: «ICNO», 66-73 (2016)

23. R. Busse, Legal regulation and organization of tax consulting in Eastern Europe on the example of Poland, the Czech Republic and Slovakia [Electronic resource]. - Mode of access: http://www.palata-nk.ru/php/content.php?id=4133

24. R. L. Dernberg, International taxation.- M.: Ed. UNITY Association; Budapest: COZPI, 375 p. (1997) 